\title{
PRINCIPLES AND PRACTICE OF AVIATION MEDICINE
}


This page intentionally left blank 


\title{
PRINCIPLES AND PRACTICE OF AVIATION MEDICINE
}

editors

\section{Claus Curdt-Christiansen}

International Civil Aviation Organization, Montreal

Jörg Draeger

University of Hamburg, Germany

Aero Medical Center, Lufthansa AG, Frankfurt, Germany

\author{
Jürgen Kriebel
}




\title{
Published by
}

World Scientific Publishing Co. Pte. Ltd.

5 Toh Tuck Link, Singapore 596224

USA office: 27 Warren Street, Suite 401-402, Hackensack, NJ 07601

UK office: 57 Shelton Street, Covent Garden, London WC2H 9HE

\author{
Library of Congress Cataloging-in-Publication Data \\ Principles and practice of aviation medicine / editors, Claus Curdt-Christiansen, \\ Jörg Draeger, Jürgen Kriebel. \\ p. ; cm. \\ Includes bibliographical references and index. \\ ISBN-13: 978-981-238-861-2 (hardcover : alk. paper) \\ ISBN-10: 981-238-861-3 (hardcover : alk. paper) \\ 1. Aviation medicine. I. Curdt-Christiansen, Claus. II. Draeger, Jörg, \\ Prof. Dr. III. Kriebel, Jürgen.
}

[DNLM: 1. Aerospace Medicine--methods. 2. Aerospace Medicine--standards,

WD 700 P952 2009]

RC1062.P75 2009

616.9'80213--dc22

2009013320

\section{British Library Cataloguing-in-Publication Data}

A catalogue record for this book is available from the British Library.

Copyright (C) 2009 by World Scientific Publishing Co. Pte. Ltd.

All rights reserved. This book, or parts thereof, may not be reproduced in any form or by any means, electronic or mechanical, including photocopying, recording or any information storage and retrieval system now known or to be invented, without written permission from the Publisher.

For photocopying of material in this volume, please pay a copying fee through the Copyright Clearance Center, Inc., 222 Rosewood Drive, Danvers, MA 01923, USA. In this case permission to photocopy is not required from the publisher.

Typeset by Stallion Press

Email: enquiries@stallionpress.com

Printed by FuIsland Offset Printing (S) Pte Ltd. Singapore 
This page intentionally left blank 


\section{Prologue}

Aviation is at the heart of world development. Man, with all his physical and mental shortcomings, is at the heart of aviation. But just as modern life is inconceivable without aviation, aviation cannot exist without its weakest link, the human being. The aviation environment, however, is hostile to humans. Soon after the first balloon flights more than 200 years ago, it became clear that man was unable to function and survive at altitude without special protection and support. With the advent of powered flight more than 100 years ago, the need for physiological and medical support became obvious. Doctors supporting the military flight operations of World War I realized that selection criteria had to be developed to reduce the high number of losses of both aircraft and pilots. Following the Peace Conference in Paris in 1919, the first international medical requirements for licensing of aviators were agreed upon, and over the ensuing years these international standards have been further developed. Since then powered flight has evolved considerably and so has the specialty of aviation medicine. The medical standards for licensing of pilots, i.e. the medical requirements an applicant must meet to be accepted for initial training and which all trained and licensed pilots must meet at their regulatory renewal examinations, have always been restrictive and conservative. This is an obvious necessity. The purpose of the requirements is to maintain and secure the high level of safety that characterizes modern aviation - a goal that leaves little 
room for experimenting with or relaxing the requirements. However, many medical conditions that were considered permanently disqualifying in the past are now allowed as a result of continuous improvement in our understanding of the physiology of flight, the evolution of evidence-based medicine, and the vast technical advances of recent years in diagnosis and treatment.

All medical standards have three different aspects that always must be considered together. The first is the requirement per se, e.g., epilepsy entails unfitness for all classes of medical certification, or blood pressure shall be within normal limits. The second aspect is the method or methods traditionally employed or sometimes prescribed by the Licensing Authority for carrying out the examination. The third aspect is the definitions applied to the requirements. For example, how is epilepsy defined or what are the normal limits for arterial tension? Although most countries have accepted the international standards and recommended practices developed and continually updated by the International Civil Aviation Organization (ICAO), there are still significant differences from one country to another pertaining to the methods of examination. Examining the visual fields of a pilot by confrontational testing with finger movements compared to examining by automated, computerized perimetry provides results on very different levels of reliability. The use of different methods of examination vary from country to country is hardly a surprise; different countries have different cultures, different socio-economical conditions, different prevalences of many diseases, different medical traditions, and different attitudes to the relevance of safety precautions.

Modern civil aviation, however, is international. A modern airliner has the same needs and demands for ground support wherever it happens to be in the world. Almost 200 countries are currently connected with each other by regular commercial flights and none can afford to reject the international community and refuse to provide the infrastructure necessary to ensure the safety of aviation. All signatories to the Convention on International Civil Aviation ("Chicago Convention") of 1944, currently totaling 191 countries, have undertaken to collaborate in securing the highest practicable degree of uniformity in relation to aircraft, aviation personnel, licensing 
procedures, etc., including medical certification of pilots and air traffic controllers. Even so, there are still significant differences regarding national approaches to aeromedical certification. To some extent, these differences are related to the influence that military aviation medicine has had upon civil aviation medicine. Also relevant is the comparative level of development that aviation medicine (as a medical specialty) has reached in different countries. While in some countries aviation medicine was a highly-developed medical specialty even before World War II, in other countries aviation medicine is only beginning to establish itself as a recognized specialty.

Most countries have agreed on the need to implement medical requirements for aviation personnel and have adopted the ICAO International Medical Standards and Recommended Practices or developed their own medical standards in accordance with the ICAO provisions. The next step towards uniformity in medical certification must be to help medical examiners and medical assessors worldwide adopt similar methods of examination and similar definitions of diseases and disorders. In particular, agreement on definitions and similar interpretation of the signs and symptoms of diseases and disorders are required if global harmonization in aeromedical certification is to be achieved.

This book contains detailed, experience-based, practical knowledge written to assist aviation medical examiners (AMEs) and other clinicians, as well as medical assessors of the Licensing Authorities, in the often confusing world of medical treatment and aeromedical evaluation of safety-critical aviation personnel such as pilots, cabin crew members, and air traffic controllers. In addition, it provides medical guidelines for physicians who have patients with medical conditions who wish to travel by air. This book is written by AMEs and clinicians from a wide range of medical specialties that are important to the field of aviation medicine. It initially began as a reference book for German physicians who may or may not be AMEs, yet who are involved in the health care of pilots. It has expanded to this current English version to address an international audience in order to provide guidance and advice to colleagues in the practice of clinical aviation medicine. Considering the European background of the authors, 
this book represents European points of view and international or European criteria regarding the determination of fitness for duty among civil aviation personnel. It is, nonetheless, an excellent and detailed international guide for medical practitioners in all parts of the world who deal with aircrew members and airline passengers.

Aviation medicine is a scientific discipline that involves the study of the physiological, psychological, operational, and environmental factors that determine the adaptive responses of a human being during flight. With regard to flight crews, the focus is different from that of the "conventional" clinical specialties which primarily deal with abnormal physiology within a normal environment, as it is concerned with normal physiology within an abnormal environment. With regard to passengers, however, conventional and aviation medicine intersect because at times abnormal physiology may be placed within an abnormal environment. This is also the case when it comes to determining exactly to what degree, i.e., with what limitations or restrictions or under what conditions, a pilot with a medical disorder may be able to perform his duties without endangering flight safety. It is to this highly specialized field of clinical aviation medicine that most chapters of the book are dedicated.

Flying represents a hostile environment that imposes a variety of physical, physiological, and psychological demands on human beings who are not genetically adapted to function in such an environment. Promoting the health and well being of aviation personnel worldwide is essential for the safety of all flight operations in civil aviation. It is also very important to recognize the potential consequences that the flight environment can have on those individuals who have pre-existing medical conditions and wish to travel by air or are required to be transported or medically evacuated by aircraft. Therefore, medical practitioners must possess basic knowledge of aviation physiology and medicine in order to make appropriate decisions concerning medical certification of pilots and other flight personnel. Such knowledge is also essential in making the correct decisions concerning the safe medical transport of diseased passengers aboard commercial aircraft or the medical transport (elective or emergency) of patients by air ambulance. 
Most university programs that train medical professionals do not include instruction in the basic principles of aviation physiology or medicine. Some countries offer basic and advanced post-graduate training in aviation medicine, but very few offer formal residency programs (specialty) in aviation medicine. Therefore, this book will benefit medical practitioners in many countries that do not have national access to post-graduate training in aviation medicine. It will also be a good source of clinical, aeromedical knowledge for those who are enrolled in post-graduate training programs in aviation medicine.

Any professional publication that contributes to our existing body of knowledge in aviation medicine is very welcome since there are not many up-to-date publications that specifically address the clinical aspects of aviation medicine. Therefore, this book represents an important addition to the international literature on aviation medicine in general, and to its clinical aspects in particular.

The contributing authors' knowledge of aviation medicine, significant clinical experiences, and international professional recognition among colleagues make this book an excellent addition to any aviation medicine practitioner's personal library.

Dr. Melchor Joaquín Antuñano Director, Civil Aerospace Medical Institute Federal Aviation Administration Past-President and Fellow, Aerospace Medical Association Past-President, Space Medicine Society Past-President, Iberoamerican Association of Aerospace Medicine Member and Chancellor of the International Academy of Aviation and Space Medicine Member of the International Academy of Astronautics Honorary Member of the Colombian, Greek, Brazilian, Mexican, Slovenian and Turkish Aerospace Medicine Societies 
This page intentionally left blank 


\title{
Preface and Acknowledgement
}

\begin{abstract}
Aviation medicine is a medical specialty which combines aspects of preventive, occupational, environmental and clinical medicine with the physiology and psychology of man in flight. It is concerned with the health and safety of those who fly, both crew and passengers, as well as the selection and performance of those who hold aviation licences.
\end{abstract}

This book provides practice-oriented information on evaluation of fitness to fly and medical certification of those who want to acquire or maintain an aviation licence. The focus is on uniform methods of examination and assessment of pilots, both professional and private, cabin crew members, and air traffic controllers. In order to increase the book's clarity and usefulness for practical application, common diseases and disorders are discussed; those rarely encountered in aviation medicine practice are excluded.

A symbolic summary of this book is depicted on the cover by the "aeromedical homunculus." As the area of anatomical representation increases with the complexity of the sensory-motor function, the sensory-motor homunculus represents the connection between different body parts and the corresponding areas in the hemispheres of the brain. The body on the left side is the motor homunculus, lying in front of the central sulcus (CS) of the brain. The bigger the body parts in this picture are, the more brainpower is required to control them. The body half on the right is the sensory homunculus, lying behind the CS. It is similar to the motor homunculus except that it 
depicts how much brain power is dedicated to receiving sensory input from the different body parts. By analogy, the "aeromedical homunculus" in the middle has organs whose relative size symbolizes their aeromedical significance. The dominance of the heart (and therefore of aviation cardiology) makes an extracorporeal depiction necessary. The importance of the eyes and ears (and therefore of aviation ophthalmology and otology) leaves hardly any room for the brain, which - being the most important of all organs - has been moved to the front and given its own, separate space. The gap where the liver should have been alludes to the easily overlooked exogenous and toxic risks.

The different sizes of the organs of the "aeromedical homunculus" are also correlated to the selection of medical topics and the degree of detail and comprehensiveness with which they are treated in the various chapters of the book.

Regarding the significance of clinical aviation medicine, one should not overlook the fact that aviation incidents and accidents have remained relatively constant in recent decades, with human factors causing or contributing to about 80 percent. This gives emphasis to the importance of aviation psychology. The criteria for mental fitness and psychological testing as well as the significance of crew coordination and cockpit resource management are described. A separate chapter deals with the less understood and often underestimated influence of psycho-social stressors. Through disruption of the man-machine interface, the problems of daily life may become a threat to aviation safety. Consequences of head injuries or diseases affecting the brain are sometimes overlooked as licence holders construct facades to hide their loss of flying skills. This is discussed in depth in a chapter on the relevant neuro-psychological conditions and disorders.

An aeromedical book intended for an international readership constantly collides with transcultural issues. In order to minimize the risk inherent in all aviation activities, international regulations (ICAO International Standards and Recommended Practices, SARPs) have been developed and agreed to by virtually all countries in the world. In this context, it is surprising that aviation medicine still exhibits 
a large degree of international variation. Each country issues its own aeromedical requirements in accordance with, but not necessarily identical with, the international SARPs of ICAO, but each country has it own aeromedical traditions and a national understanding of the medical problems involved in flying. Even the nomenclature of medical certification is not uniform, e.g. FAA Class 3 medical certification corresponds to JAA Class 2. In addition, there are still national differences with regard to the retirement age for commercial pilots, although the international age limit of 65 years is gaining global acceptance.

The editors are proud to have succeeded in acquiring the cooperation and contributions of several of the leading experts from the various fields of operational aviation medicine. The majority of these experts have for years been engaged in both the clinical and the regulatory aspects of aviation medicine in their capacity as members of the Aviation Medicine Committee of the Federal Minister of Transportation.

The physiological basis for aviation medicine, outlined by two eminent experts, provides the basic theoretical foundation for the following clinical sections.

A chapter on the history of aviation medicine gives the interested reader a stimulating insight into the methodological development of a very specialized field of medicine which, in the words of Dr. Silvio Finkelstein, former Chief of Aviation Medicine Section of ICAO is "invisible but essential."

In addition to the International Standards and Recommended Practices of ICAO, the JAR-FCL 3 medical requirements as well as the FAA rules for licensing are described.

Finally, a chapter on passenger health, written by Dr. Petra Illig, has been added. It deals with several aspects of aviation medicine of importance not only for those who practise aviation medicine but for all medical practitioners who in their daily practice meet people who fly.

Claus Curdt-Christiansen Jörg Dräger Jürgen Kriebel 
This page intentionally left blank 


\section{Acknowledgment}

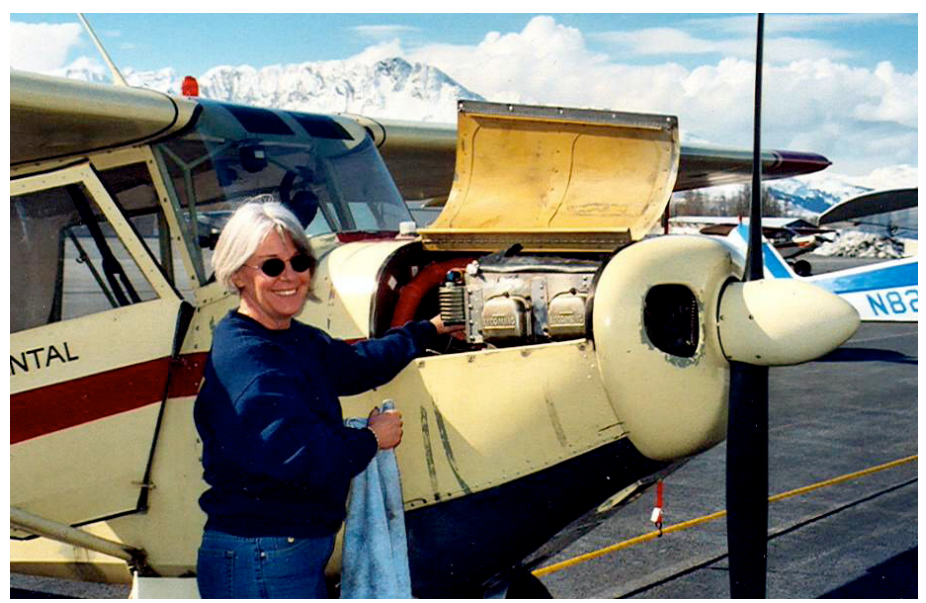

Petra checking the oil.

The editors are greatly indebted to Dr. Illig for contributing the timeconsuming work of translating "Principles and Practice of Aviation Medicine" from German to English, and wish to thank her for her commitment to a project that sometimes seemed unlikely ever to be completed.

\section{Dr. Petra A. Illig, MD, Senior FAA, Aviation Medical Examiner, Anchorage}

Dr. Petra Illig was born in Germany and immigrated to the Unites States at the age of four. She obtained her private pilot licence in 1981, a month before she graduated from the University of Washington School of Medicine. Board certified in Emergency Medicine, she worked in that field for 15 years. She became an FAA Aviation Medical Examiner in 1984, and was a Regional Medical Director of Aircrew Health Services for Delta Air Lines from 1998-2001.

Dr. Illig has a full-time Aviation Medicine practice in Anchorage, Alaska. She is also a founder of Space Medicine Associates, LLC, which provides space medicine and bioastronautics consultation to the commercial space industry.

She flies a homebuilt aircraft and enjoys living in Alaska with her two children, Peter and Lena. 
This page is intentionally left blank 


\section{Editors}

Claus Curdt-Christiansen, MD, DAvMed

Former Chief of Aviation Medicine Section, ICAO, Montreal

Former Chief Medical Officer of the Danish Civil Aviation

Administration, Copenhagen, Denmark

Fellow of the Aerospace Medical Association, USA

Jörg Draeger, MD, professor

Head of the Dept. of Ophthalmology, University of Hamburg,

Germany

Past President of the German Society of Aviation and Space

Medicine

Past Vice President of the Aerospace Medical Association, USA

Member of the Aeromedical Expert Board of the Minister for

Transportation, Germany

Jürgen Kriebel, MD, professor

Former Head of the Dept. of Neurology, Armed Forces Hospital, Academic Hospital of the University of Ulm, Germany Past President of the German Society of Aviation and Space Medicine

Member of the Scientific Board of the German Academy of Aviation and Travel Medicine 
This page intentionally left blank 


\section{List of Contributors}

Lutz Bergau, MD, AME, Occupational Health, An den Tannen 8, D-64546 Mörfelden-Walldorf, Germany, e-mail: lutz.bergau@web.de

Claus Curdt-Christiansen, MD, DAvMed, 27 Nanyang View, Singapore 639632, Republic of Singapore, e-mail: curdt3@yahoo.ca

Hans Ditschuneit, MD, prof. emerit., AME, Albert Schweitzer Straße 13, D-89134 Blaustein, Germany, e-mail: hans-ditschuneit@t-online.de

Jörg Draeger, MD, prof., Klinik und Poliklinik für Augenheilkunde, Martinistraße 52, D-20246 Hamburg, Germany, e-mail: k.sebestyen@uke.uni-hamburg.de

Rainer Facius, PhD, nuclear- and bio-physicist, German Aerospace Center (DLR), Linder Höhe, D-51147 Köln, Germany, e-mail: Rainer.Facius@dlr.de

Viktor Harsch, MD, AME, Lt.Col., Joseph Haydn Weg 5, Neubrandenburg, Germany, e-mail: FUNeubrandenburg@t-online.de

Reinhard Höltgen, MD, senior physician, cardiologist, Heart Center Duisburg, Gerrickestraße 21, D-47137 Duisburg, Germany, e-mail: reinhard.hoeltgen@ ejk.de

Petra A. Illig, MD, senior aviation medical examiner, 5011 Spenard Road, Suite 102, Anchorage, AL 995170, USA, e-mail: petra.illig@gmail.com

Herbert Jacobs, psychologist, AMC, German Armed Forces, Center of Civic Eduction and Leadership, Von Witzleben Straße 17, Koblenz, Germany, e-mail: herbertjacobs@bundeswehr.org

Ilse Janicke, MD, senior physician, cardiologist and angiologist, aero medical examiner (AME), Heart Center Duisburg, Duisburg, Germany, e-mail: ilsejanicke@ t-online.de

Reiner W. Kemmler, clinical psychologist, aviation and sports psychologist, Schillerstraße 27, D-64546 Mörfelden-Walldorf, Germany, e-mail: kemmler@ luftfahrtpsychologie.de; kemmler@aviationpsychology.de

Jürgen Kressin, MD, ENT specialist and flight surgeon, Dorfplatz 9, Berlin-Bohnsdorf, Germany, e-mail: Toni.Kressin@arcor.de

Jürgen Kriebel, MD, prof., Scultetusweg 8, D-98075 Ulm, Germany, e-mail: mail@ jkriebel.de 
Reinhard G. Matschke, MD, prof. of otorhinolaryngology, medical director, Lister Krankenhaus, Lister Kirchweg 43, Hannover, Germany, e-mail: pdrgmatschke@ onlinemed.de

Matthias M. Meier, PhD, physicist, radiation protection consultant, German Aerospace Center (DLR), Porz-Wahnheide, Linder Höhe, D-51147 Köln, Germany, e-mail: Matthias.Meier@dlr.de

Annetje Roodenburg, MD, senior aviation medical examiner, AMS, Aviation House, Hawkins Street, Dublin 2, Ireland, e-mail: annetje.roodenburg@iaa.ie

Ekkehart Rumberger, MD, prof. emerit., Willistraße 5, Hamburg, Germany

Norbert Schauer, MD, cardiologist, AME, Maria Theresien-Straße 22, A-6020 Innsbruck, Austria, e-mail: N.Schauer@tirol.com

Rüdiger Schwartz, MD, Dept. of Ophthalmology, Hamburg-University, Hamburg, Germany, e-mail: r.schwartz@uke.uni-hamburg.de

Jörg Siedenburg, MD, AME, Occupational Medicine, Aeromedical Center Lufthansa, Lufthansa-Basis, Tor 21, D-60546 Frankfurt, Germany, e-mail: Joerg.siedenburg@ dlh.de

Warren S. Silberman, D.O., MPH, Federal Aviation Agency, 800 Independence Ave. SW, Washington, DC 20591, USA, e-mail: warren.silberman@faa.gov

K. Steininger, PhD, aviation psychologist (EAAP), Beim Schäferhof 68, D-22415 Hamburg, Germany

Dirk Stelling, PhD, aviation psychologist (EAAP), German Aerospace Center (DLR e.V.), Aviation and Space Psychology/Head of COCKPIT-Division, Hamburg, Germany, e-mail: Dirk.Stelling@dlr.de

Frank Weber, MD, PD, Col, consultant neurologist, consultant psychiatrist, German Air Force Institute of Aviation Medicine, Dept. of Neurology, Postfach 1264 KFL, D-82242 Fürstenfeldbruck, Germany, e-mail: FrankWeber@bundeswehr.org

Matthias M. Weber, MD, prof., psychiatrist, assistant medical director, Max Planck Institute for Psychiatry, Kraepelinstraße, D-80804 München, Germany, e-mail: mmw@mpipsykl.mpg.de

M. Wieczorek, MD, senior physician, cardiologist and electrophysiologist, Heart Center Duisburg, Gerrickestraße 27, D-47137 Duisburg, Germany, e-mail: m.Wieczorek@ejk.de

Dietrich Wirth, MD, assist. prof., Böhmerstraße 7, D-01099 Dresden, Germany, e-mail: wirthdieosw@kabelmail.de

Josef Zihl, PhD, prof. of neuropsychology, Dept. of Psychology, University of Munich, München, Germany, e-mail: zihl@psy.Imu.de 


\section{Contents}

Prologue $\quad$ v

Preface and Acknowledgement xi

List of Abbreviations, Acronyms and Units xix

PART 1 INTRODUCTION 1

1 The History and Development of Aviation Medicine 3 Viktor Harsch

\section{PART 2 INTERNATIONAL STANDARDS} AND REQUIREMENTS

2 ICAO International Medical Standards and Recommended Practices Claus Curdt-Christiansen

3 Federal Aviation Administration - Aviation Medicine Warren S. Silberman 
4 Joint Aviation Authorities (JAA) and European

Aviation Safety Agency (EASA) - Medical Requirements for Pilots in Europe

Joerg Siedenburg and Annetje Roodenburg

\section{PART 3 PHYSIOLOGY AND RADIATION}

5 Fundamentals of Aviation Physiology

Dietrich Wirth and Ekkehart Rumberger

6 Cosmic Radiation Exposure of Flight Crews

Lutz Bergau, Rainer Facius and Matthias M. Meier

\section{PART 4 PREVENTION}

7 Physiology and Pathophysiology of Nutrition

Herwig H. Ditschuneit

\section{PART 5 CLINICAL AVIATION MEDICINE}

8 Introduction: The Role of Medical Factors 205 in Accident Investigation Ilse Janicke, Norbert Schauer, Marcus Wieczorek and Reinhard Höltgen

9 Cardiovascular Risk Factors

Norbert Schauer

10 Arterial Hypertension

Norbert Schauer

11 Heart Diseases and Disorder 
12 Coronary Artery Disease Ilse Janicke

13 Cardiac Valve Disease/Valve Replacement IIsle Janicke

14 Cardiac Rhythm and Conduction Disturbances Reinhard Höltgen and Marcus Wieczorek

15 Congenital Heart Diseases Ilse Janicke

16 Vascular Diseases and Disorders Ilse Janicke

17 Ophthalmology for the Medical Examiner Rüdiger Schwartz and Jörg Draeger

18 Ear, Nose and Throat (ENT) Medicine and Dentistry for Aeromedical Examiners Jürgen Kressin and Reinhard G. Matschke

19 Neurology for the Aeromedical Examiner Jürgen Kriebel and Frank Weber

20 Psychiatry Jürgen Kriebel and Matthias M. Weber

21 Operational and Clinical Aviation Psychology Konrad Steininger and Dirk Stelling 
22 Neuropsychological Disorders After Brain Injury and their Assessment Josef Zihl and Herbert Jacobs

23 The Man-Man Interface in the Man-Machine System of Commercial Aviation Aircraft

Reiner W. Kemmler

\section{PART 7 PASSENGERS}

24 Passenger Health

Petra A. Illig

Appendix I

Appendix II

Index 


\section{List of Abbreviations, Acronyms and Units}

ACC

ACE

AED

AeMC

AF

$\mathrm{AHA}$

Al

AIDS

AMC

AME

AMS

ANC

AP

AS

ASA

ASD

AsMA

$\mathrm{AT}_{1}$

ATP

ATPL

BPPV

BMI

American College of Cardiology

angiotensin converting enzyme

automated external defibrillator

aeromedical centre

atrial fibrillation

American Heart Association

aortic insufficiency

acquired immuno-deficiency syndrome

aeromedical center; acceptable means of compliance

authorized medical examiner

aeromedical section (of the Licensing Authority)

$\sim$ CMO's office

active noise compensation

angina pectoris

aortic stenosis

acetyl salicylic acid (Aspirin $\left.{ }^{\circledR}\right)$; atrial septal aneurysm

atrial septal defect

Aerospace Medical Association

angiotensin type 1

adenosine triphosphate

airline transport pilot licence

benign positional paroxysmal vertigo

body mass index 
BP

CAA

$\mathrm{CAB}$

CABG

CACS

CAD

CAMI

CCS

CCT

CDC

CDT

$\mathrm{CHD}$

$\mathrm{CHF}$

$\mathrm{CMO}$

CMRI

CNS

COPD

CPL

CRM

CRP

CT

CVA

D

DCS

DES

DIWS

DNA

DSM-IV

DVT

EASA

EBCT

EC

ECG blood pressure

civil aviation authority

civil aeronautics board

coronary artery by-pass graft

coronary artery calcium score

coronary artery disease

Civil Aerospace Medical Institute (in Oklahoma City)

Canadian Cardiovascular Society

cranial CT

Centers for Disease Control \& Prevention (in Atlanta)

carbohydrate-deficient transferrin

coronary heart disease

congestive heart failure

chief medical officer

cardiac MRI

central nervous system

chronic obstructive pulmonary disease

commercial pilot licence

crew resource management

C-reactive protein

computerized tomography

cerebrovascular attack

dioptre

decompression sickness

drug eluting stent

document, imaging and workflow system

deoxyribonucleic acid

Diagnostic and Statistic Manual of Mental Disorders, 4th Edition (American Psychiatric Association)

deep vein thrombosis

European Aviation Safety Agency

electron beam computed tomography

European Commission

electrocardiogram 
EEC electroencephalogram

EEMK enhanced emergency medical kits

EF ejection fraction

ENT ear, nose and throat

ESC European Society of Cardiology

EU European Union

EURATOM European Atomic Energy Community

FAA Federal Aviation Administration

FCL flight crew licensing

FFA free fatty acids

FO first officer

$g \quad$ gravity, i.e. the gravitational attraction of the Earth

G accelerative force (in multiples of g).

$\gamma$-GT gamma-glutamyl-transferase

GND ground

Gy gray

HDL high density lipoprotein

HEPA high efficiency particulate air filter

hs-CRP high-sensitivity CRP

$\mathrm{Hz} \quad$ hertz

IATA International Air Transport Association

ICAO International Civil Aviation Organization (a specialized agency of the United Nations with HQ in Montreal, Canada)

ICD implantable cardioverter defibrillator

ICD-10 International Statistical Classification of Diseases and Related Health Problems, 10th revision (WHO).

ICRP International Commission on Radiological Protection

IFR

IMA

INR

instrument flight rules

internal mammary artery

international normalized ratio

IPPPSH International Prospective Primary Prevention Study in Hypertension

IR implementing rule 
ISA international standard atmosphere

JAA Joint Aviation Authorities

JAR Joint Aviation Regulations

$\mathrm{K}$

Kelvin

$\mathrm{KeV} \quad$ kilo electron volt

LA left atrium

LAD left anterior descending coronary artery

LBBB left bundle branch block

LDL low density lipoprotein

Lp(a) lipoprotein a

LV

left ventricle

MAR minimum angle of resolution

MCV mean corpuscular volume

MEDIF medical information sheet (IATA)

MET metabolic equivalent

$\mathrm{MeV}$ mega electron volt

MIDCAB minimally invasive direct coronary artery by-pass

MRA

MRI

MS

magnetic resonance angiogram

magnetic resonance imaging

mitral stenosis

MSCT

multi-slice CT

MSL

mean sea level

$\mathrm{mSv}$

milli sievert

MVP

$\mathrm{N}$

mitral valve prolapse

newton; north

NOTAM notification for airmen

NSAID non-steroidal anti-inflammatory drug

NYHA New York Heart Association

OML

operational multicrew limitation

OSL

$P$

operational single pilot limitation

pressure

$\mathrm{Pa}$

pascal

PAC premature atrial contraction

PBW phonetically balanced words

$\mathrm{PCl}$

percutaneous coronary intervention

PE

pulmonary emboli 


$\begin{array}{ll}\text { PET } & \text { positron emission tomography } \\ \text { PFO } & \text { patent foramen ovale } \\ \text { PPL } & \text { private pilot licence } \\ \text { PS } & \text { pulmonary stenosis } \\ \text { PTCA } & \text { percutaneous transluminal coronary angioplasty } \\ \text { PTS } & \text { permanent threshold shift } \\ \text { PVC } & \text { premature ventricular contraction } \\ \text { R } & \text { specific gas constant } \\ \text { RBBB } & \text { right bundle branch block } \\ \text { RCA } & \text { right coronary artery } \\ \text { RQ } & \text { respiratory quotient } \\ \text { RV } & \text { right ventricle } \\ \text { SARP } & \text { Standards and Recommended Practices (ICAO) } \\ \text { SARS } & \text { severe acute respiratory syndrome } \\ \text { SHBG } & \text { sex hormone-binding globulin } \\ \text { SJM } & \text { St. Jude medical prosthesis } \\ \text { SODA } & \text { statement of demonstrated ability } \\ \text { SMR } & \text { standard mortality rate } \\ \text { SPECT } & \text { single photon emission computed tomography } \\ \text { SSRI } & \text { selective serotonin re-uptake inhibitor } \\ \text { SST } & \text { super sonic transport } \\ \text { STPD } & \text { standard temperature, pressure and air density } \\ \text { T } & \text { temperature } \\ \text { TEE } & \text { transesophageal echocardiography } \\ \text { TIA } & \text { transitory ischemic attack } \\ \text { TTS } & \text { temporary treshold shift } \\ \text { TUC } & \text { time of useful consciousness } \\ \text { URI } & \text { upper respiratory infection } \\ \text { V } & \text { volume } \\ \text { VAT } & \text { visceral adipose tissue } \\ \text { VF } & \text { ventricular fibrillation } \\ \text { VFR } & \text { visual flight rules } \\ \text { VOC } & \text { volatile organic compounds } \\ \text { VPN } & \text { virtual private network } \\ \text { VSD } & \text { ventricular septal defect } \\ \text { VLDL } & \text { very low density lipoprotein } \\ & \end{array}$


VT ventricular tachycardia

WHO World Health Organization (a specialized agency of the United Nations with HQ in Geneva, Switzerland)

WHR waist-to-hip ration

WOSCOPS West of Scotland Coronary Prevention Study

WPW Wolff-Parkinson-White syndrome

WRIGHT WHO Research Into Global Hazards of Travel 